\title{
Pengaruh Risiko Perusahaan dan Pajak Terhadap Konservatisme Akuntansi Pada Perusahaan Pertambangan Yang Terdaftar di Bursa Efek Indonesia
}

\author{
Reka Silvana Devi ${ }^{1}$, Endang Sri Mulatsih ${ }^{2}$ \\ 1STIE Mulia Darma Pratama, Rekasilvanadevi20@gmail.com \\ 2STIE Mulia Darma Pratama, endangsrimulatsih21@gmail.com
}

\begin{abstract}
ABSTRAK
Konservatisme merupakan sikap atau aliran dalam menghadapi ketidakpastian untuk mengambil tindakan atas dasar kemunculan yang terjelek dari ketidakpastian tersebut. Risiko perusahaan dan konservatisme akuntansi memiliki hubungan, dimana risiko perusahaan yang tinggi akan membuat manajer lebih hati-hati atau konservatif dalam mengungkapkan setiap pos laporan keuangan. Hubungan pajak terhadap konservatisme akuntansi yaitu pajak timbul dari konflik kepentingan antara perusahaan dengan pemerintah sebagai wakil dari masyarakat yang memiliki wewenang untuk melakukan pengalihan kekayaan dari perusahaan kepada masyarakat sesuai ketentuan berlaku dan dengan proses informasi akuntansi seperti laba maka jika semakin besar laba akan menyebabkan pajak yang semakin besar. Rumusan masalah dalam penelitian ini yaitu bagaimana pengaruh risiko perusahaan dan pajak terhadap konservatisme akuntansi pada perusahaan pertambangan yang terdaftar di Bursa Efek Indonesia periode 2012-2018 baik secara simultan maupun parsial. Penelitian ini bertujuan untuk mengetahui pengaruh risiko perusahaan dan pajak terhadap konservatisme akuntansi pada perusahaan pertambangan yang terdaftar di Bursa Efek Indonesia periode 2012-2018 baik secara simultan maupun parsial.Pengambilan sampel dilakukan menggunakan Purposive Sampling dengan jumlah sampel yang digunakan sebanyak 5 perusahaan pertambangan yang terdaftar di Bursa Efek Indonesia dengan periode pengamatan selama 2012-2018. Sumber data sekunder dalam penelitian ini mengambil dari BEI. Metode penelitian yang digunakan dalam penelitian ini adalah metode verifikatif. Teknik analisis data menggunakan analisis regresi logistik berganda. Berdasarkan hasil analisis yang dihasilkan risiko perusahaan tidak berpengaruh terhadap konservatisme akuntansi secara parsial dan pajak berpengaruh terhadap konservatisme akuntansi secara parsial. Sedangkan secara simultan ada minimal satu variabel x (risiko perusahaan dan pajak) yang berpengaruh terhadap konservatisme akuntansi.
\end{abstract}

Kata kunci : Konservatisme Akuntansi, Risiko Perusahaan, Pajak

\section{ABSTRACT}

Conservatism is an attitude or flow in the face of uncertainty to take action on the basis of the worst appearance of the uncertainty. The company's risks and accounting conservatism have relationships, where the company's high risk will make the manager more cautious or conservative in disclosing each post's financial statements. The tax relationship to the accounting conservatism is the tax arising from the conflicts of interest between the company and the Government as representatives of the communities who have the authority to transfer wealth from the company to the community. According to the prevailing provisions and with the process of accounting information such as profit, if the greater the profit will lead to increasingly greater taxes. The problem formulation in this research is how the influence of the company's risk and tax on the accounting conservatism on the mining companies listed on the Indonesia Stock Exchange during period 2012-2018 both simultaneously and partially. This research aims to determine the impact of the company's risk and tax on accounting conservatism in the mining companies listed on the Indonesia Stock Exchange period 2012-2018 both simultaneously and partially. Sampling is carried out using Purposive Sampling with the number of samples used by as many as 5 mining companies listed on the Indonesia Stock exchange with a period of observation during 2012-2018. The secondary data sources in this study took from ISE. The research methods used in this study are a verificative method. Data analysis techniques used multiple logistics regression analysis. Based on the results of the analysis, the company's risk has no effect on accounting conservatism partially and taxes affect accounting conservatism partially. Simultaneously there is at least one variable $x$ (company and tax risk) that affects the conservatism of accounting.

Keywords: Conservatism Accounting, Corporate Risks, Taxes. 


\section{A. PENDAHULUAN}

Laporan keuangan merupakan bahasa bisnis. Di dalam laporan keuangan berisi informasi mengenai kondisi keuangan perusahaan kepada pihak pengguna. Dengan memahami laporan keuangan suatu perusahaan, maka berbagai pihak yang berkepentingan dapat melihat kondisi kesehatan keuangan suatu perusahaan. Tujuan utama dari laporan keuangan adalah menyediakan informasi mengenai posisi keuangan, kinerja, dan perubahan ekonomi. Sedangkan peranan dari analisis laporan keuangan adalah pengambilan keputusan ekonomi dengan menggunakan informasi laporan keuangan dan informasi relevan penting (Murhadi, 2015:01)

Laporan keuangan merupakan cerminan bagi perusahaan tersebut untuk menilai hasil kinerja mereka selama beberapa periode. Perusahaan selalu berusaha untuk mendapatkan laba yang optimal dalam setiap kegiatannya, oleh karena itu perusahaan harus menentukan konsep akuntansi yang tepat dalam penyusunan laporan keuangan dan sesuai dengan keadaan perusahaan. Perusahaan memiliki sedikit kebebasan dalam memilih satu dari beberapa alternatif konsep akuntansi yang ditawarkan dalam Standar Akuntansi Keuangan (SAK), salah satu dari beberapa alternatif konsep akuntansi yang ditawarkan dalam SAK adalah konsep akuntansi konservatif (Suryandari, 2012).

Konservatisme merupakan sikap atau aliran (mazhab) dalam menghadapi ketidakpastian untuk mengambil tindakan atau keputusan atas dasar munculan (outcome) yang terjelek dari ketidakpastian tersebut. Sikap konservatif juga mengandung makna sikap berhati-hati dalam menghadapi risiko dengan cara bersedia mengorbankan sesuatu untuk mengurangi atau menghilangkan risiko (Suwardjono, 2005:245). Menurut FASB No. 2 konservatisme diartikan sebagai reaksi kehati-hatian dalam menghadapi ketidakpastian yang terjadi dalam aktivitas ekonomi dan bisnis. Watts (2003) mendefinisikan konservatisme sebagai perbedaan verifiabilitas yang diminta untuk pengakuan laba dibandingkan rugi. Tujuan perusahaan melakukan konservatisme adalah membatasi manajer berperilaku oportunistik, meningkatkan nilai perusahaan dan mengurangituntutan hukum.

\section{B. KAJIAN TEORI \\ 1) Teori Keagenan (Agency Theory)}

Teori agensi adalah kontrak diantara satu atau lebih orang (principal) melibatkan orang lain (agent) untuk melakukan beberapa layanan atas nama mereka yang melibatkan pendelegasian sebagian kewenangan pengambilan keputusan kepada agent. Hubungan antara teori keagenan (agency theory) dengan konservatisme akuntansi adalah terletak pada teori keagenan memaksa perusahaan untuk menjelaskan segala biaya maupun pendapatan yang ada didalam perusahaan tersebut. Manajer dalam mencapai hubungan yang baik antara perusahaan dengan investor akan menerapkan konsep konservatisme. Manajer harus mengungkapkan semua biaya dengan sebenar-benarnya sehingga investor akan percaya dengan apa yang diungkapkan oleh perusahaan. Dengan demikian, tidak ada lagi salah paham antara manajer dan perusahaan serta antara manajer dan investor. Hal ini disebabkan sikap manajer yang membuat nilai didalam pos-pos laporan keuangan tersebut menarik bagi investor menanamkan modal diperusahaan. 


\section{2) Konservatisme Akuntansi}

Prinsip konservatisme adalah suatu prinsip pengecualian atau modifikasi dalam hal bahwa prinsip tersebut bertindak sebagai batasan terhadap pengecualian atau modifikasi dalam hal bahwa prinsip tersebut bertindak sebagai batasan terhadap penyajian data akuntansi yang relevan dan andal. Prinsip konservatisme menganggap bahwa ketika memilih antara dua atau lebih tehnik akuntansi yang berlaku umum, suatu preferensi ditunjukkan untuk opsi yang memiliki dampak paling tidak menguntungkan terhadap ekuitas pemegang saham. Secara lebih spesifik, prinsip tersebut mengimplikasikan bahwa nilai terendah dari aktiva dan pendapatan serta nilai tertinggi dari kewajiban dan beban yang sebaiknya dipilih untuk dilaporkan. Oleh karena itu, prinsip konservatisme mengharuskan bahwa akuntan menampilkan sikap pesimistis secara umum ketika memilih teknik akuntansi untuk pelaporan keuangan. Untuk mencapai tujuan guna memahami laba dan aktiva sekarang, prinsip konservatisme dapat mengarah pada perlakuan yang merupakan penyimpangan terhadap pendekatan yang dapat diterima.

Dalam penelitian ini pengukuran konservatisme dilakukan dengan menggunakan proxy berbasis akrual Givoly dan Hayn (2000) dalam Dwi Mulyani (2010) dan Septianto (2016) yang dihitung dengan cara berikut ini:

Total Accrual $=\frac{(\text { laba bersih }+ \text { depresiasi })-\text { arus } \text { kas operasi }}{\text { Total } \text { Asset }} \times-1$

Givoly dan Hayn (2000) dalam Dwimulyani (2010) dan Septianto (2016) mengeluarkan akrual depresiasi karena merupakan akrual positif yang akan membalik ketika aset tetap diperoleh dan tidak tertangkap dalam perbedaan antara laba dan aliran kas. Ukuran konservatisme ini dikalikan -1, sehingga semakin besar nilai positif rasio, adalah semakin konservatif.

Hasil perhitungan konservatisme akuntansi ada yang negatif dan ada yang positif maka variabel konservatisme akuntansi merupakan variabel dummy. Apabila hasil perhitungan memperoleh nilai negatif maka diberi nilai 0 dan jika hasil perhitungan memperoleh nilai positif maka diberi nilai 1.

Nilai negatif $=0=$ tidak konservatisme

Nilai positif $=1=$ mengalami konservatisme

\section{3) Faktor-faktor yang Mempengaruhi Konservatisme Akuntansi}

Menurut Sinambela dan Almilia (2018) faktor-faktor yang mempengaruhi konservatisme akuntansi adalah :

1. Ukuran perusahaan

2. Risiko perusahaan

3. Intensitas modal

4. Pajak

5. Risiko litigasi

6. Debt covenant

7. Komite audit

8. Kepemilikan manajerial

Faktor-faktor yang mempengaruhi konservatisme akuntansi yang digunakan dalam penelitian ini yaitu :

a. Risiko Perusahaan 
Risiko selalu dihubungkan dengan kemungkinan terjadinya sesuatu yang merugikan yang tidak diduga/tidak diinginkan. Jadi merupakan ketidakpastian atau kemungkinan terjadinya sesuatu, yang bila terjadi akan mengakibatkan kerugian.

Risiko perusahaan dapat diartikan suatu kondisi dimana kemungkinankemungkinan yang menyebabkan kinerja suatu perusahaan menjadi lebih rendah dari apa yang diharapkan suatu perusahaan karena adanya suatu kondisi tertentu yang tidak pasti dimasa mendatang.

Kreditor berkepentingan terhadap distribusi aset bersih dan laba yang lebih rendah kepada manajer dan pemegang saham sehingga cenderung meminta manajer untuk menyelenggarakan akuntansi konservatif .

DER $=\frac{\text { Total Debt }}{\text { Total Equity }}$

\section{Sumber : (Murhadi, 2015:61)}

\section{b. Pajak}

UU Nomor 16 tahun 2009 pasal 1 ayat 1 mendefinisikan pajak sebagai kontribusi wajib kepada negara yang terutang oleh orang pribadi atau badan yang bersifat memaksa berdasarkan Undang-undang, dengan tidak mendapatkan imbalan secara langsung dan digunakan untuk keperluan negara bagi sebesar-besarnya kemakmuran rakyat.(Apriani, 2015).

Definsi pajak yang dikemukakan oleh Djajadiningrat dalam Resmi (2016:1): Pajak sebagai suatu kewajiban menyerahkan sebagian dari kekayaan ke kas negara yang disebabkan suatu keadaan, kejadian, dan perbuatan yang memberikan kedudukan tertentu, tetapi bukan sebagai hukuman, menurut peraturan yang ditetapkan pemerintah serta dapat dipaksakan, tetapi tidak ada jasa timbal balik dari negara secara langsung untuk memelihara kesejahteraan secara umum.

Pajak penghasilan (PPh) adalah pajak yang dikenakan terhadap subjek pajak atau penghasilan yang diterima atau diperolehnya dalam satu tahun pajak. Badan adalah sekumpulan orang dan/atau modal yang merupakan kesatuan baik yang melakukan usaha maupun tidak melakukan usaha yang meliputi perseroan terbatas, perseroan komanditer, perseroan lainnya, badan usaha milik negara atau badan usaha milik daerah dengan nama dan dalam bentuk apa pun, firma, kongsi, koperasi, dana pensiun, persekutuan, perkumpulan, yayasan, organisasi massa, organisasi sosial politik, atau organisasi lainnya, lembaga, dan bentuk badan lainnya termasuk kontrak investasi kolektif dan bentuk usaha tetap. (Resmi, 2016:70-71).

\section{4) Pengaruh Risiko Perusahaan Terhadap Konservatisme Akuntansi}

Risiko perusahaan dinyatakan sebagai akibat yang dapat terjadi pada perusahaan yang sifatnya merugikan dan dapat dihindari. Hal yang tidak diinginkan perusahaan adalah kerugian. Dalam menghindari kerugian perusahaan harus menciptakan laporan keuangan yang sebenar-benarnya bahkan hingga nilai setiap pos didalam laporan keuangan. Perusahaan harus berhati-hati dalam menyusun laporan keuangan terutama dalam melakukan penilaian terhadap pos-pos yang ada dalam laporan keuangan agar dapat dipertanggungjawabkan oleh perusahaan bila terdapat masalah atau risiko perusahaan. Risiko perusahaan yang tinggi akan membuat manajer akan lebih hati-hati atau konservatisme dalam mengungkapkan setiap pos laporan keuangan. Biaya politis dapat diamati dari besarnya risiko 
perusahaan. Apabila risiko perusahaan semakin besar, maka biaya politis akan semakin besar sehingga menuntut akuntansi yang lebih konservatif. Hasil penelitian Maria dan Luciana (2018) menunjukkan bahwa risiko perusahaan tidak berpengaruh signifikan terhadap konservatisme akuntansi. Rata-rata risiko perusahaan untuk nilai konservatisme diatas rata-rata memiliki nilai yang lebih tinggi dibanding rata-rata risiko perusahaan untuk nilai konservatisme dibawah rata-rata. Selisih antara ratarata risiko perusahaan untuk konservatisme akuntansi diatas dan dibawah rata-rata tidak cukup besar yang menunjukkan bahwa risiko perusahaan tidak memberikan pengaruh yang signifikan terhadap nilai konservatisme akuntansi.

\section{5) Pengaruh Pajak Terhadap Konservatisme Akuntansi}

Pajak timbul dari konflik kepentingan antara perusahaan dengan pemerintah sebagai wakil dari masyarakat yang memiliki wewenang untuk melakukan pengalihan kekayaan dari perusahaan kepada masyarakat sesuai ketentuan berlaku dan dengan proses informasi akuntansi seperti laba maka jika semakin besar laba akan menyebabkan pajak yang semakin besar (Afriani, 2017). Widya (2004) dalam Afriani (2017) bahwa perusahaan dengan laba semakin besar akan menyebabkan pajak yang semakin besar maka perhatian pemerintah juga akan semakin tertuju pada perusahaan dan semakin diatur, sehingga perusahaan cenderung ingin menghindari dari pajak yang besar ia memilih akuntansi yang lebih konservatif. Hasil penelitian Sinambela (2018) dan Afriani (2017) menunjukkan bahwa biaya pajak berpengaruh terhadap konservatisme akuntansi.

\section{6) Kerangka Pemikiran}

Berdasarkan penjelasan yang disajikan penulis mencoba memberikan kerangka pemikiran sebagai berikut.

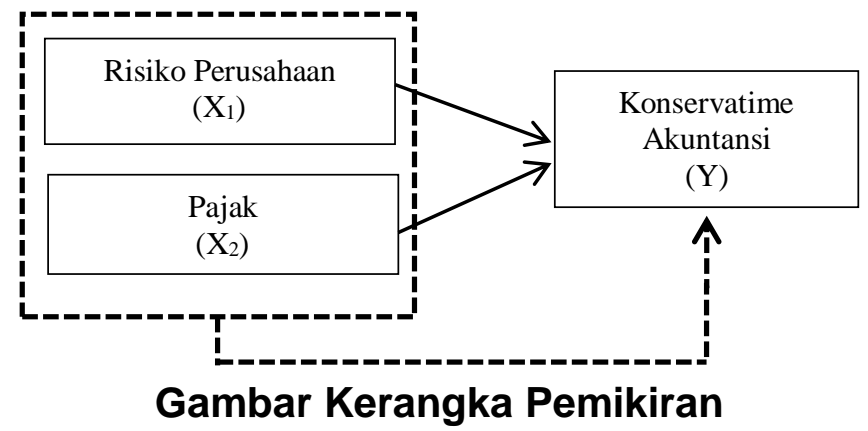

Keterangan :

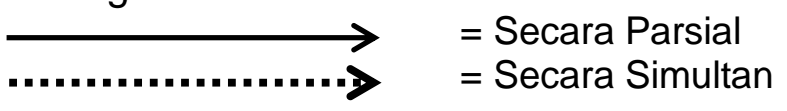

\section{7) Hipotesis}

Adapun hipotesis dalam penelitian ini adalah :

$\mathrm{H}_{1}$ : Diduga risiko perusahaan dan pajak berpengaruh secara parsial terhadap konservatisme akuntansi pada perusahaan pertambangan yang terdaftar di Bursa Efek Indonesia. 
$\mathrm{H}_{2}$ : Diduga minimal ada satu variabel independen (Risiko Perusahaan dan Pajak) yang berpengaruh terhadap konservatisme akuntansi pada perusahaan pertambangan yang terdaftar di Bursa Efek Indonesia.

\section{METODE PENELITIAN}

1. Objek Penelitian

Locus penelitian ini adalah perusahaan pertambangan yang terdaftar di Bursa Efek Indonesia tahun 2013-2018.

Objek penelitian ini adalah laporan keuangan perusahaan pertambangan yang terdaftar Bursa Efek Indonesia tahun 2012-2018.

2. Sumber Data

Seluruh data yang digunakan dalam penelitian ini adalah data sekunder, yaitu laporan keuangan perusahaan pertambangan yang terdaftar di Bursa Efek Indonesia dari tahun 2012-2018 (www.idx.co.id.)

3. Populasi dan Sampel

Populasi yang diambil sebagai objek penelitian ini adalah perusahaan pertambangan yang terdaftar di Bursa Efek Indonesia dari tahun 2013-2018. Populasi penelitian ini berjumlah 41 perusahaan.

Teknik pengambilan sampel yang dilakukan secara purposive samplingdan diperoleh 5 perusahaan yang sesuai dengan kriteria yang telah diterapkan.

\section{HASIL DAN PEMBAHASAN}

1) Perkembangan Konservatisme Akuntansi Pada Perusahaan

Pertambangan yang Terdaftar di BEl 2012-2018

Berikut ini disajikan data perkembangan Konservatisme Akuntansi pada Perusahaan Pertambangan yang terdaftar di BEI periode 2012-2018 adalah sebagai berikut :

\section{Tabel Data Perkembangan Konservatisme Akuntansi Pada Perusahaan Pertambangan yang Dijadikan Sampel Penelitian \\ (Dalam Jutaan Rupiah, kecuali dinyatakan lain)}

\begin{tabular}{|c|c|c|c|c|c|c|c|c|}
\hline No & $\begin{array}{c}\text { Kode } \\
\text { Perusahaan }\end{array}$ & Tahun & $\begin{array}{l}\text { Laba } \\
\text { Bersih }\end{array}$ & Depresiasi & $\begin{array}{c}\text { Arus Kas } \\
\text { Operasi }\end{array}$ & Total Asset & $\begin{array}{c}\text { Konservatisme } \\
\text { Akuntansi }\end{array}$ & $\begin{array}{l}\text { Variabel } \\
\text { Dummy }\end{array}$ \\
\hline \multirow{7}{*}{1} & \multirow{7}{*}{ CITA } & 2012 & 2.760 & 8.470 & 10.058 & 261.439 & $(0,004)$ & 0 \\
\hline & & 2013 & 484 & 8.517 & 5.874 & 326.960 & $(0,01)$ & 0 \\
\hline & & 2014 & 1.014 & 8.694 & (21.291) & 366.053 & $(0,08)$ & 0 \\
\hline & & 2015 & 1.950 & 8.603 & (14.164) & 605.667 & $(0,04)$ & 0 \\
\hline & & 2016 & 20.881 & 8.843 & $(8.428)$ & 615.962 & $(0,06)$ & 0 \\
\hline & & 2017 & 4.717 & 8.849 & $(79.173)$ & 700.252 & $(0,13)$ & 0 \\
\hline & & 2018 & 5.205 & 7.557 & $(26.990)$ & 735.775 & $(0,05)$ & 0 \\
\hline \multirow{7}{*}{2} & \multirow{7}{*}{ ELSA } & 2012 & 135.597 & (277.467) & 537.289 & 4.294 .557 & 0,16 & 1 \\
\hline & & 2013 & 242.605 & $(265.820)$ & 753.549 & 4.370 .964 & 0,18 & 1 \\
\hline & & 2014 & 418.092 & $(210.143)$ & 420.593 & 4.245 .704 & 0,05 & 1 \\
\hline & & 2015 & 379.745 & $(219.272)$ & 424.231 & 4.407 .513 & 0,06 & 1 \\
\hline & & 2016 & 316.066 & $(251.591)$ & 447.139 & 4.190 .956 & 0,09 & 1 \\
\hline & & 2017 & 250.754 & $(320.260)$ & 395.459 & 4.855 .369 & 0,1 & 1 \\
\hline & & 2018 & 276.316 & (352.229) & 344.756 & 5.657 .327 & 0,07 & 1 \\
\hline \multirow{6}{*}{3} & \multirow{6}{*}{ PTBA } & 2012 & 2.909 .421 & 54.022 & 2.214 .213 & 12.728 .981 & $(0,06)$ & 0 \\
\hline & & 2013 & 1.854 .281 & $(89.281)$ & 2.051 .330 & 11.677 .155 & 0,02 & 1 \\
\hline & & 2014 & 2.019 .214 & $(156.218)$ & 1.976 .117 & 14.812 .023 & 0,01 & 1 \\
\hline & & 2015 & 2.037 .111 & (278.966) & 1.897 .771 & 16.894 .043 & 0,01 & 1 \\
\hline & & 2016 & 2.024 .405 & $(326.356)$ & 1.928 .346 & 18.576 .774 & 0,01 & 1 \\
\hline & & 2017 & 4.547 .232 & (599.702) & 2.415 .444 & 21.987 .482 & $(0,07)$ & 0 \\
\hline
\end{tabular}




\begin{tabular}{|c|c|c|c|c|c|c|c|c|}
\hline & & 2018 & 5.121 .112 & $(631.050)$ & 7.867 .786 & 24.172 .933 & 0,14 & 1 \\
\hline \multirow{7}{*}{4} & \multirow{7}{*}{ RUIS } & 2012 & 28.994 & 32.329 & $(75.307)$ & 1.171 .261 & $(0,12)$ & 0 \\
\hline & & 2013 & 29.635 & 50.511 & 95.929 & 1.277 .943 & 0,01 & 1 \\
\hline & & 2014 & 55.705 & 54.311 & 62.741 & 1.264 .143 & $(0,04)$ & 0 \\
\hline & & 2015 & 41.281 & 57.996 & 245.646 & 1.091 .754 & 0,13 & 1 \\
\hline & & 2016 & 26.070 & 56.430 & 159.547 & 979.132 & 0,08 & 1 \\
\hline & & 2017 & 20.922 & 54.337 & 31.415 & 959.348 & $(0,05)$ & 0 \\
\hline & & 2018 & 27.055 & 54.262 & 23.488 & 990.372 & $(0,06)$ & 0 \\
\hline \multirow{7}{*}{5} & \multirow{7}{*}{ TINS } & 2012 & 431.589 & (389.875) & 1.006 .110 & 6.130 .320 & 0,16 & 1 \\
\hline & & 2013 & 515.102 & $(278.000)$ & (761.537) & 7.883 .294 & $(0,13)$ & 0 \\
\hline & & 2014 & 637.954 & (380.989) & (640.782) & 9.752 .477 & $(0,09)$ & 0 \\
\hline & & 2015 & 101.561 & (442.171) & 1.290 .229 & 9.279 .683 & 0,18 & 1 \\
\hline & & 2016 & 251.969 & $(507.932)$ & 1.090 .381 & 9.548 .631 & 0,14 & 1 \\
\hline & & 2017 & 502.417 & (496.911) & (152.027) & 11.876 .309 & $(0,01)$ & 0 \\
\hline & & 2018 & 531.349 & (561.518) & $(1.420 .759)$ & 15.117 .948 & $(0,09)$ & 0 \\
\hline
\end{tabular}

Sumber : www.idx.co.id (Data diolah, 2019)

PT Citatah, Tbk menunjukkan bahwa nilai konservatisme akuntansi (total accrual)pada tahun 2012-2018 memperoleh hasil negatif dan diberi nilai 0 yang artinya bahwa PT Citatah, Tbk dari tahun 2012-2018 tidak mengalami konservatif.

PT Elnusa, Tbk menunjukkan bahwa nilai konservatisme akuntansi (total accrual) pada tahun 2012-2018 memperoleh hasil positif dan diberi nilai 1 yang artinya PT Elnusa, Tbk dari tahun 2012-2018 mengalami konservatif.

PT Bukit Asam, Tbk nilai konservatisme akuntansi tahun 2012 dan 2017 memperoleh hasil negatif dan diberi nilai 0 yang artinya tidak mengalami konservatif.Tahun 2013, 2014, 2015, 2016 dan 2018 memperoleh hasil positif diberi nilai 1 yang artinya mengalami konservatif.

PT Radiant Utama Interinsco, Tbk nilai konservatisme akuntansi (total accrual) pada tahun 2012, 2014, 2017 dan 2018 memperoleh hasil negatif diberi nilai 0 yang berarti tidak mengalami konservatif.Tahun 2013, 2015, dan 2017 memperoleh hasil positif diberi nilai 1 yang artinya mengalami konservatif.

PT Timah, Tbk nilai konservatisme akuntansi (total accrual) pada tahun 2012, 2015 dan 2016 memperoleh hasil positif diberi nilai 1 yang artinya mengalami konservatif. Tahun 2013, 2014, 2017 dan 2018 memperoleh hasil negatifdan diberi nilai 0 yang artinya tidak mengalami konservatif.

\section{2) Perkembangan Risiko Perusahaan Pada PerusahaanPertambangan yang Terdaftar di BEI 2012-2018}

Berikut ini disajikan data perkembangan Risiko Perusahaan pada Perusahaan Pertambangan yang terdaftar di BEI periode 2012-2018 adalah sebagai berikut :

Tabel Data Perkembangan Risiko Perusahaan

Pada Perusahaan Pertambangan yang Dijadikan Sampel Penelitian

(Dalam Jutaan Rupiah, kecuali dinyatakan lain)

\begin{tabular}{cccccc}
\hline No Kode Perusahaan & Tahun & Total Debt & Total Equity & DER \\
\hline \multirow{4}{*}{1} & 2012 & 182.687 & 78.752 & 2,32 \\
\cline { 3 - 6 } & \multirow{3}{*}{ CITA } & 2013 & 247.724 & 79.236 & 3,13 \\
\cline { 3 - 6 } & 2014 & 285.803 & 80.250 & 3,56 \\
\cline { 3 - 6 } & 2015 & 316.679 & 288.988 & 1,1 \\
\cline { 3 - 6 } & 2016 & 301.007 & 314.955 & 0,96 \\
\cline { 3 - 6 } & 2017 & 378.839 & 321.412 & 1,18 \\
\cline { 3 - 6 } & & 2018 & 408.161 & 327.614 & 1,25 \\
\hline
\end{tabular}




\begin{tabular}{|c|c|c|c|c|c|}
\hline \multirow{7}{*}{2} & \multirow{7}{*}{ ELSA } & 2012 & 2.252 .312 & 2.042 .245 & 1,10 \\
\hline & & 2013 & 2.085 .850 & 2.285 .114 & 0,91 \\
\hline & & 2014 & 1.662 .708 & 2.582 .996 & 0,64 \\
\hline & & 2015 & 1.772 .327 & 2.635 .186 & 0,67 \\
\hline & & 2016 & 1.313 .213 & 2.877 .743 & 0,46 \\
\hline & & 2017 & 1.803 .449 & 3.051 .920 & 0,59 \\
\hline & & 2018 & 2.357 .127 & 3.300 .200 & 0,71 \\
\hline \multirow{7}{*}{3} & \multirow{7}{*}{ PTBA } & 2012 & 4.223 .812 & 8.505 .169 & 0,50 \\
\hline & & 2013 & 4.125 .586 & 7.551 .569 & 0.55 \\
\hline & & 2014 & 6.141 .181 & 8.670 .842 & 0,71 \\
\hline & & 2015 & 7.606 .496 & 9.287 .547 & 0,82 \\
\hline & & 2016 & 8.024 .369 & 10.552 .405 & 0,76 \\
\hline & & 2017 & 8.187 .497 & 13.799 .985 & 0,59 \\
\hline & & 2018 & 7.903 .237 & 16.269 .696 & 0,49 \\
\hline \multirow{7}{*}{4} & \multirow{7}{*}{ RUIS } & 2012 & 933.325 & 237.936 & 3,92 \\
\hline & & 2013 & 1.016 .045 & 261.898 & 3,88 \\
\hline & & 2014 & 953.560 & 310.583 & 3,07 \\
\hline & & 2015 & 753.340 & 338.413 & 2,23 \\
\hline & & 2016 & 619.413 & 359.719 & 1,72 \\
\hline & & 2017 & 579.059 & 380.289 & 1,52 \\
\hline & & 2018 & 584.415 & 405.957 & 1,44 \\
\hline \multirow{7}{*}{5} & \multirow{7}{*}{ TINS } & 2012 & 1.572 .120 & 4.558 .200 & 0,34 \\
\hline & & 2013 & 2.991 .184 & 4.892 .110 & 0,61 \\
\hline & & 2014 & 4.144 .235 & 5.608 .242 & 0,74 \\
\hline & & 2015 & 3.908 .615 & 5.371 .068 & 0,73 \\
\hline & & 2016 & 3.894 .946 & 5.653 .685 & 0,69 \\
\hline & & 2017 & 5.814 .816 & 6.061 .493 & 0,96 \\
\hline & & 2018 & 8.596 .067 & 6.521 .881 & 1,32 \\
\hline
\end{tabular}

Sumber : www.idx.co.id (Data diolah, 2019)

Dari tabel dapat dilihat bahwa total debt dan total equity pada perusahaan pertambangan yang terdaftar di BEI Periode 2012-2018 mengalami fluktuashal ini dibuktikan dengan hasil perhitungan DER yang berbeda-beda. Nilai DER (Risiko Perusahaan) yang semakin tinggi atau semakin meningkat akan menjadi ancaman bagi kelangsungan hidup perusahaan sehingga menuntut akuntansi yang lebih konservatif. (Pramudita, 2012).

PT Citatah, Tbk menunjukkan bahwa nilai DER pada tahun 2012 sebesar 2,32. DER tahun 2012 ke tahun 2013 mengalami peningkatan sebesar 0,81sehingga menjadi 3,13.DER tahun 2013 ke tahun 2014 mengalami peningkatan sebesar 0,43 sehingga menjadi 3,56. DER tahun 2014 ke tahun 2015 mengalami penurunan sebesar 2,46 sehingga menjadi 1,10.DER tahun 2015 ke tahun 2016 mengalami penurunan sebesar 0,14 sehingga menjadi 0,96.DER tahun 2016 ke tahun 2017 mengalami peningkatan sebesar 0,22 sehingga menjadi 1,18.DER tahun $2017 \mathrm{ke}$ tahun 2018 mengalami peningkatan sebesar 0,07 sehingga menjadi 1,25 . DERPT Citatah, Tbk dari tahun 2012-2018 cenderung mengalami nilai yang fluktuatif.

PT Elnusa, Tbk menunjukkan bahwa nilai DER pada tahun 2012 sebesar 1,10. DER tahun 2012 ke tahun 20143 mengalami peningkatan sebesar 0,19 sehingga menjadi 0,91. DER tahun 2013 ke tahun 2014 mengalami penurunan sebesar 0,27 sehingga menjadi 0,64. DER tahun 2014 ke tahun 2015 mengalami peningkatan sebesar 0,03sehingga menjadi 0,67.DER tahun 2015 ke tahun 2016 mengalami penurunan sebesar 0,21sehingga menjadi 0,46. DER tahun 2016 ke tahun 2017 
mengalami peningkatan sebesar 0,13sehingga menjadi 0,59.DER tahun $2017 \mathrm{ke}$ tahun 2018 mengalami peningkatan sebesar 0,12 sehingga menjadi 0,71 . DER PT Elnusa, Tbk dari tahun 2012-2018 cenderung mengalami penurunan.

PT Bukit Asam, Tbk menunjukkan bahwa nilai DER pada tahun 2012 sebesar 0,50. DER tahun 2012 ke tahun 2013 mengalami peningkatan sebesar 0,05 sehingga menjadi 0,55. DER tahun 2013 ke tahun 2014 mengalami peningkatan sebesar 0,16 sehingga menjadi 0,71. DER tahun 2014 ke tahun 2015 mengalami peningkatan sebesar 0,11 sehingga menjadi 0,82. DER tahun 2015 ke tahun 2016 mengalami penurunan sebesar 0,06 sehingga menjadi 0,76. DER tahun $2016 \mathrm{ke}$ tahun 2017 mengalami penurunan sebesar 0,17 sehingga menjadi 0,59 . DER tahun 2017 ke tahun 2018 mengalami penurunan sebesar 0,10 sehingga menjadi 0,49. DER PT Bukit Asam, Tbk dari tahun 2012-2018 cenderung mengalami nilai yang fluktuatif

PT Radiant Utama Interinsco, Tbk menunjukkan bahwa nilai DER pada tahun 2012 sebesar 3,92. DER tahun 2012 ke tahun 2013 mengalami penurunan sebesar 0,04 sehingga menjadi 3,88. DER tahun 2013 ke tahun 2014 mengalami penurunan sebesar 0,81 sehingga menjadi 3,07. DER tahun 2014 ke tahun 2015 mengalami penurunan sebesar 0,84sehingga menjadi 2,23.DER tahun 2015 ke tahun 2016 mengalami penurunan sebesar 0,51 sehingga menjadi 1,72 . DER tahun $2016 \mathrm{ke}$ tahun 2017 mengalami penurunan sebesar 0,20 sehingga menjadi 1,52.DER tahun 2017 ke tahun 2018 mengalami penurunan sebesar 0,08 sehingga menjadi 1,44. DER PT Radiant Utama Interinsco, Tbk 2012-2018 cenderung mengalami penurunan.

PT Timah, Tbk menunjukkan bahwa nilai DER pada tahun 2012 sebesar 0,34. DER tahun 2012 ke tahun 2013 mengalami peningkatan sebesar 0,27 sehingga menjadi 0,61. DER tahun 2013 ke tahun 2014 mengalami peningkatan sebesar 0,13 sehingga menjadi 0,74. DER tahun 2014 ke tahun 2015 mengalami penurunan sebesar 0,01sehingga menjadi 0,73.DER tahun 2015 ke tahun 2016 mengalami penurunan sebesar 0,04 sehingga menjadi 0,69. DER tahun 2016 ke tahun 2017 mengalami peningkatan sebesar 0,27sehingga menjadi 0,96.DER tahun $2017 \mathrm{ke}$ tahun 2018 mengalami peningkatan sebesar 0,36 satuan sehingga menjadi 1,32. DER PT Timah, Tbk dari tahun 2012-2018 cenderung mengalami kenaikan.

\section{3) Perkembangan Data Pajak Pada Perusahaan Pertambangan yang Terdaftar di BEI 2012-2018}

Berikut ini disajikan data perkembangan Pajak pada Perusahaan Pertambangan yang terdaftar di BEl periode 2012-2018 adalah sebagai berikut :

Tabel Data Perkembangan Pajak Pada Perusahaan Pertambangan yang Dijadikan Sampel Penelitian

\begin{tabular}{|c|c|c|c|c|}
\hline No & $\begin{array}{c}\text { Kode } \\
\text { Perusahaan }\end{array}$ & Tahun & $\begin{array}{l}\text { Beban Pajak } \\
\text { Penghasilan }\end{array}$ & $\begin{array}{c}\text { LN Pajak } \\
\text { Penghasilan }\end{array}$ \\
\hline \multirow{7}{*}{1} & \multirow{7}{*}{ CITA } & 2012 & Rp 439.000 .000 & 19,90 \\
\hline & & 2013 & Rp1.442.000.000 & 21,09 \\
\hline & & 2014 & Rp370.000.000 & 19,73 \\
\hline & & 2015 & Rp2.038.000.000 & 21,44 \\
\hline & & 2016 & Rp5.883.000.000 & 22,50 \\
\hline & & 2017 & Rp2.231.000.000 & 21,53 \\
\hline & & 2018 & Rp 4.136.000.000 & 22,14 \\
\hline
\end{tabular}




\begin{tabular}{|c|c|c|c|c|}
\hline \multirow{7}{*}{2} & \multirow{7}{*}{ ELSA } & 2012 & Rp75.474.000.000 & 25,05 \\
\hline & & 2013 & Rp 94.595.000.000 & 25,27 \\
\hline & & 2014 & Rp 141.609.000.000 & 25,68 \\
\hline & & 2015 & Rp 127.993.000.000 & 25,58 \\
\hline & & 2016 & Rp102.252.000.000 & 25,35 \\
\hline & & 2017 & Rp 75.612.000.000 & 25,05 \\
\hline & & 2018 & Rp75.491.000.000 & 25,05 \\
\hline \multirow{7}{*}{3} & \multirow{7}{*}{ PTBA } & 2012 & Rp1.002.166.000.000 & 27,63 \\
\hline & & 2013 & Rp607.081.000.000 & 27,13 \\
\hline & & 2014 & Rp655.512.000.000 & 27,21 \\
\hline & & 2015 & Rp626.685.000.000 & 27,16 \\
\hline & & 2016 & Rp672.511.000.000 & 27,23 \\
\hline & & 2017 & Rp 1.520.551.000.000 & 28,05 \\
\hline & & 2018 & Rp1.677.944.000.000 & 28,15 \\
\hline \multirow{7}{*}{4} & \multirow{7}{*}{ RUIS } & 2012 & Rp19.233.000.000 & 23,68 \\
\hline & & 2013 & Rp26.727.000.000 & 24,01 \\
\hline & & 2014 & Rp22.209.000.000 & 23,82 \\
\hline & & 2015 & Rp27.379.000.000 & 24,03 \\
\hline & & 2016 & Rp 27.924.000.000 & 24,05 \\
\hline & & 2017 & Rp 16.953.000.000 & 23,55 \\
\hline & & 2018 & Rp 17.525.000.000 & 23,59 \\
\hline \multirow{7}{*}{5} & \multirow{7}{*}{ TINS } & 2012 & Rp 204.740.000.000 & 26,05 \\
\hline & & 2013 & Rp257.101.000.000 & 26,27 \\
\hline & & 2014 & Rp 345.734.000.000 & 26,57 \\
\hline & & 2015 & Rp 66.602.000.000 & 24,92 \\
\hline & & 2016 & Rp131.921.000.000 & 25,61 \\
\hline & & 2017 & Rp 207.297.000.000 & 26,06 \\
\hline & & 2018 & Rp 191.669.000.000 & 25,98 \\
\hline
\end{tabular}

Sumber : www.idx.co.id (Data diolah, 2019)

Dari tabel diatas dapat dilihat beban pajak penghasilan badan pada perusahaan pertambangan yang terdaftar di BEI periode 2012-2018 mengalami yang fluktuasi. Pajak yang semakin meningkat maka perhatian pemerintah juga akan semakin tertuju pada perusahaan dan semakin diatur, sehingga perusahaan cenderung memilih akuntansi yang lebih konservatif.

PT Citatah, Tbk menunjukkan bahwa pajak tahun 2012 ke tahun 2013 mengalami peningkatan sebesar 228\%. Pajak tahun 2013 ke tahun 2014 mengalami penurunan sebesar 74\%. Pajak tahun 2014 ke tahun 2015 mengalami peningkatan sebesar 451\%. Pajak tahun 2015 ke tahun 2016 mengalami peningkatan sebesar 189\%. Pajak tahun 2016 ke tahun 2017 mengalami penurunan sebesar 62\%. Pajak tahun 2017 ke tahun 2018 mengalami peningkatan sebesar 85\%. Pajak PT Citatah, Tbk dari tahun 2012-2018 cenderung mengalami nilai fluktuatif.

PT Elnusa, Tbk menunjukkan bahwa pajak tahun 2012 ke tahun 2013 mengalami peningkatan sebesar 25\%.Pajak tahun 2013 ke tahun 2014 mengalami peningkatan sebesar 50\%. Pajak tahun 2014 ke tahun 2015 mengalami penurunan sebesar 9\%. Pajak tahun 2015 ke tahun 2016 mengalami penurunan sebesar 20\%. Pajak tahun 2016 ke tahun 2017 mengalami penurunan sebesar 26\%. Pajak tahun 2017 ke tahun 2018 mengalami penurunan sebesar 0,16\%. Pajak PT Elnusa, Tbk dari tahun 2012-2018 cenderung mengalami nilai fluktuatif.

PT Bukit Asam, Tbk menunjukkan bahwa pajak tahun 2012 ke tahun 2013 mengalami penurunan sebesar 39\%.Pajak tahun 2013 ke tahun 2014 mengalami 
peningkatan sebesar 8\%. Pajak tahun 2014 ke tahun 2015 mengalami penurunan sebesar 4\%. Pajak tahun 2015 ke tahun 2016 mengalami peningkatan sebesar 7\%. Pajak tahun 2016 ke tahun 2017 mengalami peningkatan sebesar 126\%. Pajak tahun 2017 ke tahun 2018 mengalami penurunan sebesar 10\%. Pajak PT Bukit Asam, Tbk dari tahun 2012-2018 cenderung mengalami kenaikan.

PT Radiant Utama Interinsco, Tbk menunjukkan bahwa pajak tahun 2012 ke tahun 2013 mengalami peningkatan sebesar 39\%.Pajak tahun 2013 ke tahun 2014 mengalami peningkatan sebesar 17\%. Pajak tahun 2014 ke tahun 2015 mengalami peningkatan sebesar 23\%. Pajak tahun 2015 ke tahun 2016 mengalami peningkatan sebesar 2\%. Pajak tahun 2016 ke tahun 2017 mengalami penurunan sebesar 39\%. Pajak tahun 2017 ke tahun 2018 mengalami peningkatan sebesar 3\%. Pajak PT Radiant Utama Interinsco dari tahun 2012-2018 cenderung mengalami nilai penurunan.

PT Timah, Tbk menunjukkan bahwa pajak tahun 2012 ke tahun 2013 mengalami peningkatan sebesar 26\%. Pajak tahun 2013 ke tahun 2014 mengalami peningkatan sebesar 34\%. Pajak tahun 2014 ke tahun 2015 mengalami penurunan sebesar 81\%. Pajak tahun 2015 ke tahun 2016 mengalami peningkatan sebesar 98\%. Pajak tahun 2016 ke tahun 2017 mengalami peningkatan sebesar 57\%. Pajak tahun 2017 ke tahun 2018 mengalami penurunan sebesar 7\%. Pajak PT Timah, Tbk dari tahun 2012-2018 cenderung mengalami nilai fluktuatif.

\section{4) Analisis Statistik Deskriptif}

Data statistik deskriptif yang menjelaskan tentang nilai minimum, maksimum, rata-rata (mean) dan standar devisiasi dari masing-masing variabel penelitian yaitu melalui program SPSS ver.22.0 yang dijelaskan pada tabel berikut ini:

\section{Tabel Hasil Analisis Statistik Deskriptif}

Descriptive Statistics

\begin{tabular}{|c|c|c|c|c|c|}
\hline & $\mathrm{N}$ & Minimum & Maximum & Mean & Std. Deviation \\
\hline RISIKO PERUSAHAAN (X1) & 35 & ,34 & 3,92 & 1,3191 & 1,02554 \\
\hline PAJAK (X2) & 35 & 19,73 & 28,15 & 24,7460 & 2,23506 \\
\hline KONSERVATISME AKUNTANSI (Y) & 35 & 0 & 1 &, 51 &, 507 \\
\hline Valid N (listwise) & 35 & & & & \\
\hline
\end{tabular}

Sumber : Data diolah SPSS, 2019

Dari tabel hasil analisis statistik deskriptif dapat kita ketahui bahwa risiko perusahaan sendiri terdiri dari 35 sampel dengan nilai minimum sebesar 0,34 , maximum sebesar 3,92, rata-rata (mean) sebesar 1,3191 dan standar deviation sebesar 1,02554. Pajak sendiri terdiri dari 35 sampel dengan nilai minimum sebesar 19,73,maximum sebesar 28,15, rata-rata (mean) sebesar 24,7460 dan standar deviationsebesar 2,23506. Konservatisme akuntansi sendiri terdiri dari 35 sampel dengan nilai minimum sebesar 0 , maximum sebesar 1, rata-rata (mean) sebesar 0,51 dan standar deviation sebesar 0,507. 


\section{5) Uji Kelayakan Model Regresi}

Untuk melihat apakah data empiris sesuai dengan model sehingga model dapat dikatakan fit, kecocokan atau kelayakan model regresi secara keseluruhan dalam hal ini digunakan uji Hosmer and Lemeshow's test dengan kriteria sebagai berikut:

a. Jika nilai Hosmer and Lemeshow 0,05 artinya ada perbedaan signifikan antara model dengan observasinya sehingga goodness fit tidak baik, karena model tidak dapat memprediksi nilai observasinya.

b. Jika nilai Hosmer and Lemeshows 0,05 artinya model mampu memprediksi nilai observasinya atau dapat dikatakan bahwa model dapat diterima karena cocok dengan data observasinya. berikut:

Uji Hosmer and LemeshowGoodness of Fit dapat ditunjukkan pada tabel Tabel Menguji Kelayakan Model Regresi
Hosmer and Lemeshow Test

\begin{tabular}{|c|c|c|c|}
\hline Step & Chi-square & Df & Sig. \\
\hline 1 & 7,928 & & ,339 \\
\hline
\end{tabular}

Sumber : Data diolah SPSS, 2019

Pada tabel menunjukkan nilai Chi-square sebesar 7,928 dengan signifikansi sebesar 0,339 . Berdasarkan hasil tersebut, karena nilai signifikansi lebih besar dari 0,05 maka model dapat disimpulkan mampu memprediksi nilai observasinya atau dapat disimpulkan mampu memprediksi nilai observasinya atau dapat dikatakan model dapat diterima karena cocok dengan data observasinya.

\section{6) Analisis Regresi Logistik}

Untuk menguji hipotesis adanya pengaruh risiko perusahaan dan pajak terhadap konservatisme akuntansi akan digunakan analisis regresi logistik. Analisis regresi logistik berganda digunakan karena variabel dependen merupakan data yang berbentuk dikotomi atau variabel dummy. Dalam penelitian ini variabel dependennya konservatisme akuntansi yang hasilnya ada negatif dan positif yang diukur dengan data dikotomi yaitu nilai 0 yang menunjukkan tidak konservatisme dan nilai 1 menunjukkan mengalami konservatisme. Dengan demikian untuk mengetahui pengaruh masing-masing variabel independen terhadap variabel dependen pada penelitian ini. Hasil pengolahan data oleh SPSS 22 diperoleh hasil sebagai berikut :

Tabel Hasil Analisis Regresi Logistik Variables in the Equation

\begin{tabular}{|c|c|c|c|c|c|c|}
\hline & B & S.E. & Wald & $\mathrm{Df}$ & Sig. & $\operatorname{Exp}(B)$ \\
\hline Step $1^{\mathrm{a}} \mathrm{X} 1$ & ,687 &, 430 & 2,552 & 1 & , 110 & 1,987 \\
\hline $\mathrm{X} 2$ & ,606 & 258 & 5,508 & 1 & 019 & 1,834 \\
\hline Constant & $-15,978$ & 6,756 & 5,593 & 1 & 018 &, 000 \\
\hline
\end{tabular}

a. Variable(s) entered on step 1: $X 1, X 2$.

Sumber : Data diolah SPSS, 2019

Berdasarkan hasil uji regresi logistik dari tabel, maka persamaan regresi yang didapat adalah sebagai berikut: 


$$
Y=-15,978+0,687 X_{1}+0,606 X_{2}
$$

a. Nilai konstanta sebesar $-15,978$ berarti apabila semua variabel independen(risiko perusahaan dan pajak) bernilai Omaka variabel dependen (konservatisme akuntansi) akan bernilai sebesar -15,978.

b. Nilai koefisien risiko perusahaan sebesar 0,687 (dengan nilai positif).Nilai tersebut memberikan makna jika risiko perusahaan meningkat 1 satuan maka akan meningkatkan konservatisme akuntansi sebesar 0,687 satuan dengan asumsi variabel lain konstan. Sebaliknya jika risiko perusahaan menurun 1 satuan maka akan menurunkan konservatisme akuntansi sebesar 0,687 satuan dengan asumsi variabel lain bernilai konstan.

c. Nilai koefisien pajak sebesar 0,606 (dengan nilai positif) memberikan makna jika pajak meningkat 1 satuan maka akan meningkatkan konservatisme akuntansi sebesar 0,606 satuan dengan asumsi variabel lain konstan. Sebaliknya jika pajak menurun 1 satuan maka akan menurunkan konservatisme akuntansi sebesar 0,606 satuan dengan asumsi variabel lain bernilai konstan.

\section{7) Uji Parsial (Uji Wald)}

Pada uji Wald, pengujian hipotesis akan dilakukan secara individual atau secara parsial. Pengujian hipotesis dilakukan dengan cara memasukkan satu persatu variabel risiko perusahaan dan pajak terhadap konservatisme akuntansi. Pengujian ini untuk mengetahui pengaruh risiko perusahaan dan pajak terhadap konservatisme akuntansi:

Tabel Hasil Uji Wald

Variables in the Equation

\begin{tabular}{rrrrrrrr}
\hline \multirow{2}{*}{ Step 1 } & & B & S.E. & Wald & Df & Sig. & Exp(B) \\
\cline { 2 - 9 } & X1 &, 687 &, 430 & 2,552 & 1 &, 110 & 1,987 \\
\cline { 2 - 8 } & Constant & $-15,978$ & 6,756 & 5,593 & 1 &, 018 &, 000 \\
\hline
\end{tabular}

a. Variable(s) entered on step 1: $X 1, X 2$.

Sumber : Data diolah SPSS, 2019

Berdasarkan tabel hasil pengujian secara parsial sebagai berikut:

1. Pengujian koefisien risiko perusahaan

Berdasarkan tabel diatas dapat diketahui bahwa diperoleh nilai wald sebesar 2,552 (sig. 0,110). Nilai signifikan 0,110 lebih besar dari tingkat signifikansi sebesar 0,05 (5\%). Maka dapat disimpulkan bahwa $\mathrm{H}_{0}$ diterima atau menolak $\mathrm{H}_{a}$ yaitu variabel risiko perusahaan tidak berpengaruh signifikan terhadap konservatisme akuntansi.

Naik turunnya risiko perusahaan tidak berpengaruh terhadap konservatisme akuntansi.

2. Pengujian koefisien pajak

Berdasarkan tabel diatas dapat diketahui bahwa diperoleh nilai wald sebesar 5,508 (sig. 0,019). Nilai signifikansi 0,019 lebih kecil dari tingkat signifikansi sebesar 0,05 (5\%). Maka dapat disimpulkan bahwa $\mathrm{H}_{0}$ ditolak atau menerima

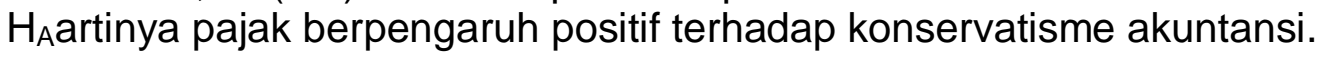

Variabel pajak bertanda positif (+) menunjukkan bahwa semakin besar pajak mengakibatkan perusahaan memiliki kecenderungan untuk melakukan konservatisme akuntansi. Sebaliknya semakin kecil jumlah pajak perusahaan 
memiliki kecenderungan konservatisme akuntansi semakin kecil. Nilai odd ratio sebesar 1,834 menunjukkan bahwa semakin tinggi pajak akan meningkatkan kecenderungan perusahaan melakukan konservatisme akuntansi sebesar 1,834 kali lebih tinggi dibandingkan dengan perusahaan yang pajaknya rendah.

\section{8) Uji Simultan (Uji Overall Model fit)}

Uji overall Model Fit atau uji simultan ini adalah untuk menguji variabel risiko perusahaan dan pajak di dalam regresi logistik secara serentak atau simultan mempengaruhi variabel konservatisme akuntansi. Uji overall model fit ini dihitung dari perbedaan nilai -2LL antara model dengan hanya terdiri dari konstanta dan model yang diestimasi terdiri dari konstanta dan variabel risiko perusahaan dan pajak Uji 2LL mengikuti distribusi chi square dengan derajat kebebasan (degreeof freedom) akan ditampilkan pada tabel.

\section{Tabel Nilai -2LL yang Hanya Terdiri Dari Konstanta Iteration History $\mathbf{a , b}, \mathbf{c}$}

\begin{tabular}{lllll}
\hline & \multicolumn{2}{c}{ Coefficients } \\
Iteration & -2 Log likelihood & \multicolumn{3}{c}{ Constant } \\
\hline Step 0 & 1 & & 48,492 & \\
& 2 & 48,492 &, 057 \\
\hline a Con & & 057 \\
\hline
\end{tabular}

a. Constant is included in the model.

b. Initial -2 Log Likelihood: 48,492

c. Estimation terminated at iteration number 2 because parameter estimates changed by less than ,001.

Sumber : Data diolah SPSS, 2019

Hasil output SPSS pada tabel merupakan nilai -2 log likelihood yang terdiri dari konstanta saja. Nilai -2 log likelihood yang hanya memasukkan konstantasaja adalah sebesar 48,492 .

Tabel Nilai -2LL yang Terdiri Dari Konstanta dan Variabel Bebas Iteration History $\mathbf{a}, \mathrm{b}, \mathrm{c}, \mathrm{d}$

\begin{tabular}{llllll}
\hline & & & \multicolumn{3}{c}{ Coefficients } \\
Iteration & \multirow{2}{*}{-2 Log likelihood } & Constant & X1 & X2 \\
Step 1 & 1 & 38,481 & $-11,086$ &, 500 &, 424 \\
& 2 & 37,855 & $-14,906$ &, 649 &, 566 \\
& 3 & 37,828 & $-15,917$ &, 684 &, 604 \\
& 4 & 37,828 & $-15,977$ &, 687 &, 606 \\
& 4 & 37,828 & $-15,978$ &, 687 &, 606 \\
\hline
\end{tabular}

a. Method: Enter

b. Constant is included in the model.

c. Initial -2 Log Likelihood: 48,492

d. Estimation terminated at iteration number 5 because parameter estimates changed by less than , 001 .

Sumber : Data diolah SPSS, 2019

Hasil output pada tampilan merupakan nilai -2 likelihood yang terdiri dari kontanta dan variabel bebas. Nilai-2 log likelihood yang memasukkan konstantadan variabel bebas adalah sebesar 37,827. Perbandingan kedua nilai -2 log likelihood tersebutsebesar 10,664. Seperti yang telah ditunjukkan pada tabel Chi Square pada. 


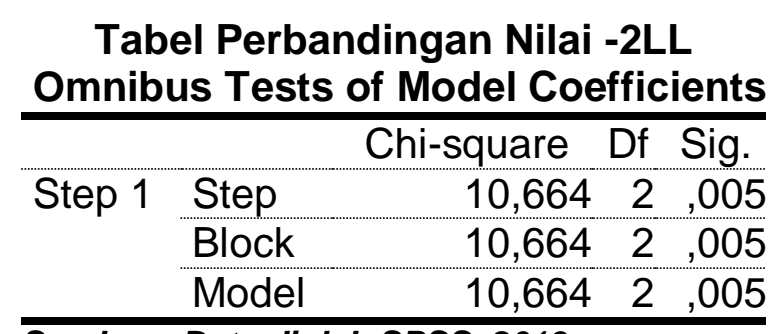

Sumber : Data diolah SPSS, 2019

Tabel diatas merupakan tampilan perbandingan nilai -2 Log likelihood yang terdiri dari konstanta saja dan -2 log likelihood yang terdiri dari konstanta dan variabel bebas (tabel 10). Perbandingan tersebut mengikuti sebaran chi square. Nilai chi square sebesar 10,664 dengan df 2. Berdasarkan tabel diperoleh nilai Sig. Model sebesar 0,005 karena nilai ini lebih kecil dari 0,05 maka dapat disimpulkan bahwa ada satu variabel $x$ (risiko perusahaan dan pajak) berpengaruh terhadap konservatisme akuntansi.

\section{9) Uji Koefisien Determinasi $\left(\mathbf{R}^{2}\right)$}

Koefisien determinasi ini digunakan untuk mengetahui seberapa besar persentase sumbangan variabel independen terhadap variabel dependen. Hasil pengujian koefisien determinasi menyajikan sebagai berikut:

Tabel Koefisien Determinasi $\left(\mathbf{R}^{2}\right)$ Model Summary

\begin{tabular}{lccc}
\hline Step & -2 Log likelihood & Cox \& Snell R Square & Nagelkerke R Square \\
\hline 1 & $37,828^{\mathrm{a}}$ &, 263 &, 350 \\
\hline a. Estimation terminated at iteration number 5 because parameter estimates changed by less than \\
,001.
\end{tabular}

Sumber : Data diolah SPSS, 2019

Besarnya nilai koefesien determinasi pada model regresi logistik ditunjukkan olehnilai Nagelkerke R Square. Nilai Nagelkerke R Square adalah sebesar 0,350 yang berartikontribusi variabel bebas yaitu risiko bebasdan pajakterhadap konservatisme akuntansi adalah sebesar $35 \%$, sedangkan sisanya sebesar $65 \%$ (100\%-35\%)dikontribusikan oleh variabel lain yang tidak diteliti dalam penelitian ini.Angka koefisien 35\% merupakan angka yang tidak terlalu tinggi namun ada pengaruhnya, hal ini dapat menunjukkan bahwa variabel risiko perusahaan dan pajak mempunyai pengaruh terhadap konservatisme akuntansi.

\section{E. KESIMPULAN DAN SARAN \\ 1. Kesimpulan}

Berdasarkan hasil penelitian dan pembahasan yang telah dilakukan tentang pengaruh risiko perusahaan dan pajak terhadap konservatisme akuntansi pada perusahaan pertambangan yang terdaftar di BEI periode 2012-2018, maka dapat ditarik kesimpulan sebagai berikut:

a) PT Citatah, Tbk (CITA) dari tahun 2012-2018 tidak mengalami konservatisme.

PT Elnusa, Tbk (ELSA) dari tahun 2012-2018 mengalami konservatisme. PT

Bukit Asam (PTBA) tahun 2012 dan 2017 tidak mengalami konservatisme 
sedangkan tahun 2013, 2014, 2015, 2016 dan 2018 mengalami konservatisme. PT Radiant Utama Interinsco tahun 2012, 2014, 2017, dan 2018 tidak mengalami konservatisme sedangkan tahun 2013, 2015 dan 2016 mengalami konservatisme. PT Timah, Tbk tahun 2012, 2015 dan 2016 mengalami konservatisme sedangkan tahun 2013, 2014, 2017, dan 2018 tidak mengalami konservatisme.

b) Risiko perusahaan (DER) PT Citatah, Tbk (CITA) tahun 2012-2018 risiko perusahaannya cenderung mengalami nilai fluktuatif. PT Elnusa, Tbk (ELSA) tahun 2012-2018 risiko perusahaannya cenderung mengalami penurunan.PT Bukit Asam (PTBA) tahun 2012-2018 risiko perusahaannya cenderung mengalami nilai yang fluktuatif. PT Radiant Utama Interinsco, Tbk (RUIS) tahun 2012-208 risiko perusahaannya cenderung mengalami penurunan. PT Timah, Tbk (TINS) tahun 2012-2018 risiko perusahaannya cenderung mengalami kenaikan.

c) PT Citatah, Tbk (CITA) tahun 2012-2018 pajaknya cenderung mengalami nilai fluktuatif. PT Elnusa, Tbk (ELSA) tahun 2012-2018 pajaknya cenderung mengalami nilai fluktuatif. PT Bukit Asam, Tbk (PTBA) tahun 2012-2018 pajaknya cenderung mengalami kenaikan. PT Radiant Utama Interinsco, Tbk (RUIS) tahun 2012-2018 pajaknya cenderung mengalami penurunan.PT Timah, Tbk (TINS) tahun 2012-2018 pajaknya cenderung mengalami nilai fluktuatif.

d) Hasil uji $t$ menunjukkan naik turunnya Risiko Perusahaan $\left(X_{1}\right)$ tidak berpengaruh terhadap Konservatisme Akuntansi (Y) pada perusahaan Pertambangan yang terdaftar di Bursa Efek Indonesia Periode 2012-2018. Sedangkan naik turunnya Pajak $\left(\mathrm{X}_{2}\right)$ berpengaruh terhadap Konservatisme Akuntansi $(Y)$ pada perusahaan Pertambangan yang terdaftar di Bursa Efek Indonesia Periode 2012 -2018.

e) Hasil uji $F$ menunjukkan bahwa minimal ada satu variabel independen (Risiko Perusahaan dan Pajak) berpengaruh positif dan signifikan terhadap variabel dependen (Konservatisme Akutansi) pada perusahaan Pertambangan yang terdaftar di Bursa Efek Indonesia periode 2012-2018.

f) Nilai koefisien determinasi Nagelkerke $R$ Square adalah sebesar 0,350 yang berartikontribusi variabel bebas yaitu risiko bebasdan pajak terhadap konservatisme akuntansi adalah sebesar 35\%, sedangkan sisanya sebesar $65 \%(100 \%-35 \%)$ dikontribusikan oleh variabel lain yang tidak diteliti dalam penelitian ini. Angka koefisien 35\% merupakan angka yang lemah tidak terlalu tinggi namun ada pengaruhnya, hal ini dapat menunjukkan bahwa variabel risiko perusahaan dan pajak mempunyai pengaruh terhadap konservatisme akuntansi.

\section{Saran}

Berdasarkan hasil kesimpulan diatas, maka penulis dapat memberikan beberapa saran antara lain sebagai berikut :

a) Bagi perusahaan

Sebaiknya pihak perusahaan memperhatikan variabel risiko perusahaan dan pajak pada suatu perusahaan bahwa semakin tinggi risiko perusahaan dan pajak maka semakin tinggi pula konservatisme akuntansi dan akan meningkatkan para investor dalam menanamkan modalnya pada perusahaan tersebut. 
b) Bagi Investor

Penelitian ini memberikan masukan kepada investor untuk melakukan pertimbangan investasi kepada perusahaan pertambangan dan mengambil keputusan untuk menambahkan modalnya.

c) Bagi Penelitian Selanjutnya

Bagi penelitian berikutnya disarankan untuk dapat meneliti dengan menambahkan variabel-variabel yang lain yang dapat mempengaruhi konservatisme akuntansi yang tidak diteliti dalam penelitian ini. Dan juga diharapkan untuk menambahkan jumlah sampel yang lebih banyak.

\section{DAFTAR PUSTAKA}

Apriani, Meri. 2017. Faktor-faktor yang Mempengaruhi Konservatisme Akuntansi pada Perusahaan Manufaktur yang Terdaftar di BEI (2008-2011). Vol. 2 No. 1

Dwimulyani, Susi. 2010. Konservatisme Akuntansi dan Sengketa Pajak Penghasilan. Jakarta : Simposium Nasional Akuntansi XIII Purwekerto

Murhadi, Werner R. 2015. Analisis Laporan Keuangan Proyeksi dan Valuasi Saham. Jakarta : Salemba Empat

Pramudita, N. 2012. Pengaruh Financial distress dan Leverage terhadap Konservatisme Akuntansi. Jurnal IImiah Mahasiswa Akuntansi, Vol 1 No.2

Resmi, Siti. 2016. Perpajakan Teori dan Kasus Edisi 9 Buku 1. Jakarta : Salemba Empat

Septianto, Hery. 2016. Pengaruh Debt Covenant, Financial Distress, Risiko Litigasi dan Growth Opportunities Terhadap Konservatisme Akuntansi [skripi]. Ekonomi dan Bisnis. Universitas Islam Negeri Syarif Hidayatullah. Jakarta

Sinambela, Maria. dkk. 2018. Faktor-faktor yang mempengaruhi konservatisme akuntasi. Jurnal Ekonomi dan Bisnis. ISSN 1979-6471 E-ISSN 2528-0147. Vol 21 No. 2

Suryandari, Erni dan Priyanto, Rangga Eka. 2012. "Pengaruh Risiko Litigasi Dan Tingkat Kesulitan Keuangan Perusahaan Terhadap Hubungan AntaraKonflik Kepentingan Dan Konservatisme Akuntansi." JurnalAkuntansi dan Investasi Vol. 12 No. 2, halaman: 161-174.

Suwardjono. 2005. Teori Akuntansi Perekayasaan Pelaporan Keuangan. Yogyakarta : BPFE-Yogyakarta

www.idx.co.id 